удк 349.2

В. М.Зеленський

\title{
ВІДСУТНІСТЬ ОФІЦІЙНО ВИЗНАНОЇ ДОКТРИНИ ТРУДОВОГО ПРАВА ЯК ВАЖЛИВА ПРОБЛЕМА ПРАВОВОГО РЕГУЛЮВАННЯ ПРИПИНЕННЯ ТРУДОВИХ ПРАВОВІДНОСИН В УКРАЇНІ
}

Актуальність теми та постановка проблеми. Питання правового регулювання припинення трудових відносин в Україні зовсім не $є$ новим. Йому приділяють чималу наукову увагу. Лише за період незалежності було захищено більше десятка дисертаційних робіт рівня кандидатського дослідження щодо окремих аспектів правового регулювання припинення трудових правовідносин (наприклад, роботи О.А. Близнюк, А.Я. Бартківа, О.С. Вареника, Л.Ю. Величко, С.М. Глазько, Ю.А. Джепи, Ю.В. Ісаєва, І.А. Іонникової, О.О. Конопельцевої, А.А. Курової, О.В. Прудивуса, Л.М. Русаль, С.В. Селезень, О.О. Чумака, В.Р. Шишлюк, 0.А. Яковлєва та іншіх). До того ж питанням припинення трудових відносин та їх належному правовому врегулюванню приділяють увагу не тільки на рівні дисертаційних досліджень, але й, як показує аналіз наукової періодики, практично всі видатні фахівці науки трудового права як то М.І.Іншин, С.М. Прилипко, Н.М. Хуторян, Г.І. Чанишева, О.М. Ярошенко, - підіймають ці проблеми в науковій періодиці, часто вказуючи на слушні прогалини, які не були досі винайдені дослідниками-дисертантами, та вносячи логічні та обгрунтовані пропозиції щодо їх вирішення. Отже, маємо констатувати, що на сьогодні вже накопичилася чимала кількість наукових робіт щодо проблем правового регулювання припинення трудових правовідносин в Україні, як щодо чинного трудового законодавства, так і щодо проектованих положень різних редакцій Трудового кодексу (далі - ТК) України.

Разом із тим, питання вивчення проблем правового регулювання припинення трудових правовідносин все ж не втрачає своєї актуальності в силу того, що, по-перше, у своїй більшості вони так і не вирішені, по-друге, триває розробка Проекту ТК України й маємо надію, що він все-таки вбере в себе дійсно досягнення наукової думки, по-третє, сплив часу та нові життєві обставини (як то неочікувані воєнні дії в нашій державі) ставлять перед науковцями все нові й нові завдання, які вони намагаються розв'язати не тільки в межах теперішніх наукових концепцій, але й виходячи за них та, відповідно, формуючи нові.

Отже, маємо на меті в даному дослідженні вкотре привернути увагу науковців до проблеми відсутності одностайно узгодженої (відповідно офіційно закріпленої) доктрини трудового права, що негативним чином впливає і на якість правового регулювання припинення трудових правовідносин в нашій державі.

Виклад основного матеріалу. Наявні проблеми правового регулювання припинення трудових правовідносин слід поділити на загальні та спеціальні. Загальні стосуються всієї системи трудового права, тому, хоча й здійснюють суттєвий вплив на можливості вирішення суто спеціальних проблем у сфері припинення трудових правовідносин, все ж є достатньо об'ємними й не можуть бути предметом даної наукової розвідки. Прикладом такої загальної проблеми може бути відсутність 
офіційно встановленої в державі доктрини трудового права, потреба в якій сьогодні гостро відчувається через наявні категоричні суперечності щодо предмета науки трудового права (відповідно, щодо тих правовідносин, які є предметом науки трудового права та мають бути предметом правового регулювання майбутнім ТК України). Ця проблема загального характеру породжує окремі види спеціальних проблем, як наприклад, штучно створена В.А. Андроновою плутанина [1] навколо припинення «індивідуальних» трудових правовідносин та підстав припинення «колективних» трудових правовідносин (до яких, до речі, вчена віднесла підписання угоди, колективного договору уповноваженими представниками сторін; припинення діяльності відповідно профспілок, їх об’єднань та організацій, їх об'єднань у встановленому законом порядку, прийняття рішення примирною комісією, трудовим арбітражем, а також вирішення спору за допомогою страйку, а не ті підстави, які застосовуються при колективних звільненнях (як то ліквідація суб'єкта господарювання чи його банкрутство)).

Прикладом загальної проблеми є також невідповідність національного законодавства міжнародним та європейським стандартам, яка знову ж таки при «звуженні» контексту породжує спеціальну проблему щодо відповідності положень інституту припинення трудових правовідносин вимогам та стандартам міжнародних та європейських правових актів. Ще одним прикладом загальної проблеми є відсутність узагальнення судової практики щодо вирішення трудових спорів в Україні за останні 20 років, яка при звуженні контексту до проблем припинення трудових правовідносин висвітлюється як проблема відсутності узагальнення судової практики щодо вирішення трудових спорів саме з означеного напрямку.

Наприклад, щодо проблеми відповідності норм чинного та проектованого національного законодавства вимогам Європейського союзу (далі - $Є \mathrm{C}$ ), міжнародним стандартам в сфері праці можна вказати наступне. Зважаючи на європейські перспективи України важливим питанням сьогодення є не просто вдосконалення правового регулювання припинення трудових правовідносин, а й одночасне його приведення у відповідність до стандартів $Є С$ у сфері використання найманої праці. Цікавим в цьому контексті є науковий доробок Л.В.Вакарюк щодо визначення чинників, які забезпечують правовий режим в трудовому праві України. Так, вчена виділяє два рівні означених чинників - міжнародний та державний. При цьому до міжнародних вона відносить «таку сукупність обставин та явищ міжнародного рівня, що спрямовують регулюючий вплив на суспільні відносини з приводу використання найманої праці в певному одноманітному та єдиному дусі у визначеному міжнародними органами та організаціями напрямку» [2, с. 50], зокрема: «1) через входження України в ООН необхідність слідування програмам ООН, МОП щодо забезпечення відповідного рівня правового регулювання праці в нашій державі, в тому числі необхідність забезпечення основних трудових прав, таких як свобода праці, недискримінація в галузі праці, тощо, та гарантій для працівників; 2) у зв'язку з обранням євроінтеграційного курсу необхідність привести національне трудове законодавство у відповідність до європейських стандартів та вимог» [2, с. 50]. Дослідниця звернулася до результатів наукової роботи О.Ю. Білоус, в дисертаційному дослідженні якої вказується, що станом на 2017 рік «Україна ратифікувала 
71 конвенцію, в тому числі 8 із 8 фундаментальних конвенцій, 4 із 4 пріоритетних конвенцій, 59 із 177 технічних конвенцій. Водночас у національній юридичній практиці відбувається часткове невиконання взятих на себе зобов'язань із ратифікації конвенцій МОП та приведення вітчизняного законодавства у відповідність із міжнародними трудовими стандартами» (цитовано за [3, с. 15-16]). Україна ратифікувала усі 8 фундаментальних конвенцій МОП. Проте до цього часу не всі положення зазначених конвенцій імплементовані у чинне трудове законодавство. Не враховані вони повною мірою й у проекті ТК України [3, с. 17]. Що ж до необхідності привести національне трудове законодавство у відповідність до вимог та стандартів ЄС, то дослідниця доходить висновку про те, що хоча і більшість норм в нашому законодавстві є вже передбачені, але все ж вони переважно є тільки деклараціями й на практиці не застосовуються і в непоодиноких випадках взагалі немає і не передбачено механізму їхньої реалізації. Тому вона наголошує на тому, що «лишень нормативно-правових приписів недостатньо задля забезпечення правового режиму, як це видно з аналізу імплементації антидискримінаційних норм в національне трудове законодавство. А тому й існує ще один важливий рівень чинників забезпечення правового режиму в трудовому праві України - це державний рівень» [2, с. 52]. А державному рівню вчена приділяє увагу у двох інших своїх дослідженнях, виділяючи серед важливих державних чинників забезпечення правового режиму в трудовому праві державну політику щодо основних засад використання найманої праці, тобто наявність правового акта-доктрини чи стратегії щодо подальшого напрямку розвитку трудового законодавства [4, с. 104]. Це є важливе зауваження, оскільки воно вказує на наявність такої проблеми в правовому регулюванні припинення трудових правовідносин, яка безпосередньо не відбиває iї, але є загальною відносно цього інституту трудового права і здійснює суттєвий вплив на його якість.

Так, відсутність офіційно визнаної доктрини в науці трудового права призводить до нелогічних формулювань положень проекту ТК, на чому вже неодноразово наголошували різні вчені. Наочним прикладом цих неточностей є, наприклад, формулювання ст. 78 проекту щодо підстав припинення трудових правовідносин. Так, як вже вище зазначалося, В.А. Андронова з теоретичної точки зору справедливо виокремила підстави припинення «колективних» трудових правовідносин. Одразу ж виникло питання щодо правомірності такого застосування через те, що в міжнародній практиці такий термін використовується для позначення масових вивільнень. Разом із тим, якщо поставити питання «а чому виникло таке непорозуміння?», то стане зрозуміло, що відповідь знаходиться в площині доктрини науки трудового права. Так, сьогодні існує по суті два напрямки розвитку трудового права: це виділення трудових та тісно пов'язаних із ними правовідносин; та другий варіант - це існування індивідуальних та колективних трудових правовідносин. Очевидно, що розробники проекту ТК поєднали в його положеннях обидві доктрини, що суперечить засадам логіки та, відповідно, негативним чином відбиватиметься на правозастосуванні, оскільки створюватиме плутанину. Так, наприклад, С.В. Вишневецька ще у 2009 році, аналізуючи проект ТК в тодішній редакції, казала про ці проблеми, зауважуючи, що в ньому відсутня цільна концептуальна 
основа: «Так, у чинному КЗпП України відсутня окрема глава, присвячена колективним трудовим відносинам. Натомість у проекті Трудового кодексу України Книга шоста має назву «Колективні трудові відносини». Хоча у ст. 2 немає чіткого зазначення, що Трудовим кодексом регулюються саме індивідуальні трудові й колективні трудові відносини, відсутнє визначення трудових відносин.... Такий стан речей свідчить про наявність методологічних проблем у науці трудового права, які потребують свого вирішення» [5, с. 64]. I хоча редакція проекту ТК була декілька разів змінена, все ж вказані зауваження до концептуального змісту проекту залишаються актуальними: так само сьогодні не визначено поняття трудових відноси, так само немає чіткого посилання на те, що кодексом регулюються індивідуальні та колективні трудові відносини, і так само Книга 6 проекту має назву «колективі трудові відносини». Отже, вірно з цього приводу підкреслює С.В.Вишневецька: «Парадигма трудового права і його ідеологія тісно пов'язані, ідеологія лежить в основі формування парадигми, справляє вирішальний вплив на зміст теорії трудового права, в основі якої лежить світоглядна позиція дослідження... При цьому під парадигмою розуміють вихідну концептуальну схему, модель постановки проблем i їх вирішення, методів дослідження, які пануюють протягом певного історичного періоду, теорію, яку втілену в системі понять, які виражають істотні риси дійсності» [5, с. 63].

B.В. Жернаков вже у більш пізній період (2016) також зазначає: «Аналіз проекту Трудового кодексу дозволяє зробити висновок, що він не має загальної концептуальної основи. Якщо за парадигму його формування брати розвиток ринкових відносин у сфері праці, то тоді виникає багато питань. Наприклад, чому у ньому далеко не повністю реалізовано засади договірної свободи працівника і роботодавця, не відбито нові тенденції у розвитку форм зайнятості й реалізації права на працю і так далі» [6, с. 12]. Далі вчений слушно та аргументовано наводить наступне: «Не можна підтримати розробників проекту у тому, що метою Кодексу е встановлення прав та обов'язків суб'єктів тільки трудових правовідносин (ст. 1 проекту ТК). Не потребує доведення, що предметом трудового права й об'єктом регулювання законодавства про працю (насамперед Кодексу) є не тільки трудові відносини, а й інші, тісно з ними пов'язані - із розгляду трудових спорів, із нагляду і контролю за дотриманням законодавства про працю і так далі. Так, суб'єктами є не тільки працівник і роботодавець, а об'єктом - відносини у процесі праці. Слід усвідомлювати, що у цих та декількох інших інститутах виникають міжгалузеві відносини, що спільно регулюються нормами як трудового права, так і конституційного, адміністративного, цивільно-процесуального, кримінально-виконавчого та інших галузей права. Та й сам текст ст. 1 про це свідчить: якщо у ч. 1 ідеться про трудові відносини, то у ч. 2 цієї статті згадуються відносини з нагляду і контролю за дотриманням трудового законодавства (які трудовими точно не можна визнати)» [6, с. 12]. Також дослідник виступає категорично проти (і ми в цьому його підтримуємо) визнання колективних трудових відносин предметом регулювання ТК: «Безумовно, процес праці зумовлює виникнення споріднених відносин, суб'єктами яких, у тому числі, можуть бути й суб'єкти «не індивідуального» характеру (трудові колективи, профспілки, об'єднання профспілок і профспілкових організацій і так далі) - 
як індивідуальних (наприклад, із вирішення трудових спорів), так і колективних (ті ж колективні трудові спори, укладення та реалізація колективних договорів). Інколи їх називають колективними трудовими відносинами, і у цієї позиції є свої прихильники, які наводять вагомі аргументи. Проте зауважимо, що, по-перше, не індивідуальний характер ще не означає колективний характер (наприклад, хіба є колективом об’єднання профспілок?), по-друге, назвати їх трудовими можна умовно, бо вони не виникають із безпосереднього процесу оплачуваної, організованої, найманої праці» [6, с. 13].

Окрім того, він вірно наголошує на тому, що розробники проекту припустилися елементарної логічної помилки, коли введи в термінологію проекту поняття «правонаступництва» у трудових правовідносинах (при реорганізації, ліквідації юридичної особи тощо), адже, як справедливо пише В.В. Жернаков, «правонаступництво - це перехід прав і обов' язків від одного суб'єкта до іншого, що неможливе у трудових правовідносинах з їх особистісним характером. Працівник, який залишається працювати в умовах зміни організаційно-правової форми роботодавця, не може сам собі передавати права та обов'язки» [6, с. 14]. Як бачимо, відсутність концептуальної основи прямим чином впливає і на логічність та якість перспективного трудо-правового врегулювання припинення трудових правовідносин.

Відтак, відсутність офіційно визнаної доктрини розвитку трудового права призводить до того, що знижується якість законодавства, а звідси й ефективність захисту трудових прав.

Висновок. Таким чином, хоча ми спостерігаємо, що в науці існують, попри усебічний критичний та відповідальний підхід до наукових розвідок, попри намагання кожного науковця найти справді істину щодо порушених проблем та шляхів їхнього вирішення, суперечності між науковцями з одного й того ж питання - це є наслідком не поганої якості наукових розвідок, а науковим плюралізмом, в якому відбивається багатогранність людської природи й можливість відповіді на питання з різних сторін. Саме тому, по суті, і потребуються подальші наукові дискусії, обговорення, і насамкінець - вироблення єдиної наукової трудо-правової доктрини, яка не заперечуватиме можливість існування інших, відмінних думок та позицій, тобто не буде зводитися до ідеологічної цензури, але буде спрямовувати науковий хід в єдиному напрямку, залишаючи місце для внесення коректив завдяки існуванню тих самих відмінних позицій. Про те, що науці трудового права потребується наукова доктрина вже неодноразово говорилося різними дослідниками, але поки офіційних зрушень щодо цього питання не відбулося.

\section{Jimepamypa:}

1. Андронова В.А. Юридичні факти у трудовому праві України : автореф. дис. к.ю.н.: 12.00.05 / Нац. ун-т «Одеська юридична академія». Одеса, 2014. 22 с.

2. Вакарюк Л.В. Чинники, що забезпечують правовий режим у трудовому праві України. Вчені записки ТНУ імені В.І. Вернадського. Серія «Юридичні науки». Том 29 (68) № 2 2018. С. 48-52.

3. Білоус О.Ю. Конвенції Міжнародної організації праці як джерела трудового права України: автореф.дис.к.ю.н.: 12.00.05 / Національний університет «Одеськаюридична академія». Одеса, 2017. 20 c.

4. Вакарюк Л.В.Державні чинники, що забезпечують правовий режим в трудовому праві України. Підприємниитво, господарство і право. 2018, № 4. С. 103-107. 
5. Вишневецька С.В. Теоретико-методологічний аспект науки трудового права. Актуальні проблеми держави і права. 2009. № 46. С. 61-67.

6. Жернаков В.В. Кодифікація законодавства про працю : теоретичні засади і практика їх реалізації. Право та інновації. 2016. № 1(13). С. 11-16.

\section{Анотація}

Зеленський В. М. Відсутність офіційно визнаної доктрини трудового права як важлива проблема правового регулювання припинення трудових правовідносин в Україні. - Стаття.

Статтю присвячено черговому наголошенню на тому, що науці трудового права потрібна узгоджена офіційно визнана наукова доктрина. Розкривається ця проблема в контексті проблем правового регулювання припинення трудових правовідносин в Україні.

Ключові слова: доктрина, трудове право, припинення трудових правовідносин, проблеми, правове регулювання.

\section{Аннотация}

Зеленский В. М. Отсутствие официально признанной доктрины трудового права как важная проблема правового регулирования прекращения трудовых правоотношений в Украине. - Статья.

Статья посвящена очередному подчеркиванию того, что науке трудового права нужна согласованная официально признана научная доктрина. Раскрывается эта проблема в контексте проблем правового регулирования прекращения трудовых правоотношений в Украине.

Ключевые слова: доктрина, трудовое право, прекращения трудовых правоотношений, проблемы, правовое регулирование.

\section{Summary}

Zelenskyi V.M. The absence of the labor law doctrine, recognized officially, as an important problem of legal regulation of terminating the employer-employee relations in Ukraine. - Article.

The article is devoted to yet another emphasizing the fact that the science of labor law requires the coherent, officially recognized scientific doctrine. This issue is disclosed in the context of problems of legal regulating the termination of employer-employee relations in Ukraine. As a result, it is emphasized that developing the single scientific labor law doctrine should not deny the availability of another thoughts and position, that is, it is not reduced to the ideological censorship, but should steer the scientific movement into the joint action, leaving the place for making adjustments due to the existence of those very positions.

Key words: doctrine, employment (labor) law, termination of employer-employee relations, problems, legal regulation. 